\title{
Ideological Conflicts in a Collection of Short Stories of Kera Di Kepala (A Monkey on the Head) by Soeprijadi Tomodihardjo: A Study of Michel Foucault's Critical Discourse Analysis
}

\author{
Titik Indarti Setya Yuwana Sudikan \\ Surabaya State University
}

\begin{abstract}
The novelty of this research is the construction of CDA Foucault's theory on a collection of short stories of Kera Di Kepala (A Monkey On The Head) by Soeprijadi Tomodihardjo (ST) (2006). The contribution of this research strengthens the concept of ideological contestation in CDA theory. The purpose of this research is to find a counter ideology against the dominant ideology in the New Order and Reformation Order in Indonesian exil literature. The theory used by CDA Michel Foucault. Research approach of constructionist Jorgensen and Phillips (2002). The data source for the collection of short stories of Kera Di Kepala (A Monkey On The Head) by ST. Technique of collecting data is critical reading, recording, coding data. CDA of Foucault's perspective data analysis technique follows Alba-Juez's (2009) formula, namely: (1) topic selection, (2) data deepening, (3) theme identification, (4) searching for absent/hidden discourse elements, (5) search for meaning relations between elements of discourse, and (6) contextualization of discourse elements in the power-knowledge network. Findings: ideology of democracy-socialist-humanism as a counter ideology for the exile authors of 1965 which was fought with liberaldemocracy ideology as the dominant ideology of the New Order and Reformation-Order governments in Indonesia. Keywords: conflict, ideology, critical discourse analysis, humanism-socialist

DOI: $10.7176 /$ RHSS/10-22-07
\end{abstract}

Publication date: November $30^{\text {th }} 2020$

\section{Introduction}

ST is the author of the 1965 Indonesian exiles who was productive both before and after the exiles. He was born in Pare, Kediri, February 27, 1933. His last education was B-1, majoring in Economics in Surabaya. He taught at SMEA Negeri in Surabaya. He attended journalism studies under the East Java Information Bureau in 1964-1965. His journalistic practice is in the Trompet Masyarakat newspaper in Surabaya, as well as a successor to literary editors Djamil Suherman and Gerson Poyk and Hertoto. In addition, he was also the editor of the Brawidjaja magazine, which later changed the name of the magazine to Wijaya, which stopped publishing in 1965.

In his position as a member of the Persatuan Wartawan Indonesia (Indonesian Journalist Union), ST once joined a group of 15 PWI members throughout Indonesia to Beijing for a month-long coverage (October 1965). Considering that at the end of September the 1965 tragedy occurred in Indonesia, he decided to become a translator at the Xinhua news agency (Hsinhua) in Beijing. ST, then moved to Western Europe and worked at the Secretariat of the Universitaetskliniken Koeln (Koeln University Hospital) until 1998 (retired).

During the New Order era, ST published literary books, including the anthology of the short story of Suara Anak Semang and the poetry anthology of Ilalang (1987). During the Reformation Era, several of his short stories appeared in the Indonesian mass media, such as: Kompas, Jawa Pos, and Lampung Pos. KPG published his short story of Kera Di Kepala (2006). Some of his popular short stories appear in Titian (September 2007) and Lobakan (July, 2009). His collection of short stories, Cucu Tukang Perang, was published by Akar Indonesia (2011), and a collection of short stories of Lelaki Pencari Langit was published by Koekoesan (2012).

The short stories in the book of Kera Di Kepala present the conflicts of various ideologies including: marxism, communism, liberalism, secularism, racism, and socialist-realism. ST is not a silly song to fight for the ideology of marxism and communism as the group of writers of Lekra was in before the September 1965 tragedy in Indonesia. There is an openness to accept and fight for any ideology that is seen in accordance with their conscience. There is no one best ideology, and no one that is worst. All contextual.

Previous research on Indonesian exile literature in 1965 was conducted by Sipayung (2011). The results of this research are: 1) Indonesian exiles become stateless people with a background in the international context of the Cold War and the national political situation; 2) the exile journey fosters collective emotional ties regarding the country of origin and the trajectory of exile; and 3) the meaning of home to exiles is not static and must be identified across two or more countries according to the different exiles' routes.

Hill (2009) criticized the Australian media, politicians or academics for not caring about victims after the G30S incident in Indonesia. The victims in question are exiles who cannot return home and live in another country. Exiles are a group or community that is fractured or divided. They do not have freedom of speech even as they struggle to obtain asylum of politic or citizenship status. Exiles in exile have produced works such as autobiographies, novels (in English and Indonesian), magazines and journals, poetry and drama, anthologies, 
collections of short stories and essays. These works cannot be separated from their journey to become an exile.

Fajar (2017) states that ST's position in Europe makes it difficult for him to remember his life in Indonesia as a true homeland. By narrating memories, ST tries to claim his Indonesian identity, even though he has to negotiate that identity in Europe, where he now lives with patience and struggle. By writing stories that tell a lot about the life of Indonesia's exiles in Europe, ST emphasized and identified himself as an inseparable part of his homeland. He imagined and reconstructed his memories of Indonesia in the thoughts and stories he told.

Choir (2018) states that ST's short stories in the book of Cucu Tukang Perang are dealing with issues of daily life for exiles that give rise to various tensions between today's realities and memories of the past, between where they live today (here) with hometown (there). This tension resulted in the ambivalence experienced by the characters in Soeprijadi's short stories. The tug-of-war gave rise to desperate protests. On the other hand, it resulted in an identity crisis.

Wijaya (2018) emphasizing the background of exiles as people who are excluded from traveling and are apparently influencing the literary pattern of travel, namely the depiction of the world and the representation of the other. The literary pattern of travel can be understood that exiles have a multi-layered world, namely: between Indonesia and the West. This layered world also indicates the problems experienced by exiles, namely the problem of inferiority in front of the West and the longing for a homeland. The negotiations carried out by the exiles were to present Indonesia in a Western country. The Indonesia presented is a community that is structured hierarchically. In order to get out of his problem, the exiled author continues to present himself and Indonesia as inferior to the West. The strategy implied to politic and ethics, namely the ethics infringement of authors to make Indonesia be inferior and also non-exiles immigrant.

The study uses Michel's critical discourse analysis of theory of Foucault. Foucault (1972) defines discourse as "general domain of statements", discourse is sometimes to be the general domain of all statements, sometimes as statements from a group of individuals, and sometimes a number of policy practices for multiple statements. Foucault's concept (1972) of discourse is an ideological articulation of reality formed by groups competing with each other to fight for the truth of historical interpretation, including literary discourse. Therefore discourse is an ideological construction used to legitimize, defend and fight for power.

Based on the study of relevant previous research, there is no research on ideological contestation in ST's short stories. The contribution of this research to science, namely strengthen the concept of ideological contestation in CDA theory. The novelty of this research lies in the construction of Foucault's CDA theory.

\section{Method}

This type of research is qualitative-explorative. Sources of research data collection of ST's short stories entitled Kera Di Kepala were published in the Gramedia Popular Library (KPG) in 2006. In this book, there are 14 short stories, namely: "Bernstein Jewels" (Permata Bernstein), "Living Hard in the West" (Hidup Berat Di Barat), "Dolls" (Boneka), "Sarma", (Sarma)", "A Monkey on the Head" (Kera Di Kepala), "Names Stay Names" (Nama Tinggal Nama), "Rumors of Birds" (Kabar Burung), "Morning in the Garage" (Pagi Hari di Garasi)," Ancient Jars", (Guci Kuno)", "Cremation", (Kremasi), "Tinnitus", (Tinnitus)", "Wolf", (Serigala), "A Long Line of Lines", (Serentang Garis Panjang) and "Lintang Kemukus". Data analysis from CDA Foucault's perspective follows the Alba-Juez (2009) formula and Scheurich and McKenzie (2005), namely: (1) topic selection, (2) deepening data, (3) identifying themes, (4) searching for absent/hidden elements of discourse, (5) searching for meaning relations between elements of discourse, and (6) contextualizing elements of discourse in power-knowledge networks.

\section{Data Analysis}

ST (2006) fights several ideologies to be contested with the dominant ideology in the collection of short stories of Kera Di Kepala, namely: Marxist ideology is found in 3 short stories, ideology of racism in 2 short stories, ideology of communism in 2 short stories, ideology of liberalism in 2 short stories, ideology of realism socialism in 1 short story, ideology of closeness in 1 short story, and ideology of secularism in 1 short story. ST has broad insight into his works, no longer childish to fight for the ideology of communism as 'life and death' in literary works, as did the Lekra (Lembaga Kebudayaan Rakyat) or People's Cultural Institute group before the September 1965 tragedy in Indonesia.

\section{Contestation of a Counter Ideology against a Dominant Ideology 1) Critique of Marxist Ideology}

In the short story entitled Bernstein Jewel by ST, there is data about the ideological conflic within the character Alex. This figure understands very well the ideology of the People's Republic of China (PRC) to rule the world which is constrained by the Marxist ideology, which opposes social class. Look at the following data.

... At that time he was fishing, why did we go to the West and not want to stay in Germany. East Germany means. He said, people could study anything there, they could even ask for a Stipendium. Not to forget he also made a sarcasm against the PRC. "They are plagued by big state ambitions." Alex replied in his journalist style. 
"Not yet at the American level. But the conditions they have: vast land, fierce industry, lots of oil, no less experts, abundant population, there is only one hurdle. " "What obstacles do you think?" Suddenly he was interested in the chattering Alex, "wanted to get first-hand information. "Internal party conflict! The class struggle in the top level leadership, "replied my friend rather excitedly (Tomodihardjo, 2006: 2-3).

The data can be interpreted that in Alex's head there is an understanding of another ideology besides the Pancasila ideology, namely the Marxist ideology. Marxist ideology gripped the Communist Party of the People's Republic of China (PRC) in the form of class opposition to the top leaders. ST's ideology that adheres to social class division is seen as an obstacle for the PRC to dominate the world.

In the short story of Names Stay Names there is also a Marxist ideology that looks down on migrant workers to Germany. There is a class difference between native Germans and migrants as workers in the German state. Look at the following data.

Gerd himself doesn't know how many generations he has lost his identity. What is clear is that he often stands out as if he is a real German. Ah, what the hell. The important thing is that I can work in the workshop where Gerd is an angel: the ridicule his fellow students usually throw at him as the nagging head of the workshop.

At first I didn't have the impression that Gerd hated the immigrants who flooded into his country. "Two million Gastarbeiters! Not counting the dark work! They are robbing jobs so that unemployment in Germany continues to increase. " he said. Gerd obviously forgot, Gastarbeiter was actually invited to his country under a bilateral work agreement when Germany needed their manpower. After the war without the Gastarbeiter Germany would not achieve the prosperity it is today. But Gerd tends to chew on the views of rightist conservatives who want to drive foreigners out of his country. They insisted that all German embassies be more stringent in granting visas and controlling passports (Tomodihardjo, 2006: 53-54).

From this data, it can be understood that foreign workers are the second social class, while the first social class is native Germans. Native Germans are more powerful than foreign workers or immigrants. There is a desire of the migrant workers to fight and negotiate, but they are helpless.

In the short story Pagi di Garasi, ST presents an ideological conflict between the 1965 Indonesian exiles and the authorities, through a dialogue between the Gardener and Mrs. Lacoste regarding the right to live in Indonesia. Look at the following data.

"It's not her fault. It's not my fault. I gave up. I didn't live for five years, I didn't know. Her right to sue for divorce. It is permissible in Islam."

"And you said it was not your fault? Ah, Mister Gardener, you are talking nonsense! "

"Yes, Mrs. Lacoste, just tell me it's all my fault. Five years I left her by going to Germany. She doesn't receive a living from me, her biological needs are not fulfilled. Her right to sue for divorce. It was also at the insistence of her parents, because there was no hope waiting for me. She's married again. I love her very much, but I give it up. Can you understand? "

"How can I understand? Mister displaced her. You run away from your responsibilities as a husband. "

"What can I do, I'm exile, Mrs. Lacoste. There is no place in my country. "

"This gentleman is very strange. Where does your wife live? "

"In Lhokseumawe."

"Lok... Lok... which hell is that?"

"North Sumatra, Madam. Indonesia. Heaven! Not hell. Heaven for rulers. Hell for me. You understand?"

"So. This gentleman is Indonesian. Mister Gardener?" (Tomodihardjo, 2006: 83).

This data can be interpreted that Indonesia is 'heaven for the rulers' and 'hell for the exiles 1965'. There was an ideological conflict voiced by the 1965 exiles through the Gardener figure. There is a ruling social class and a powerless social class represented by the 1965 exiles who were displaced in other lands. The powerlessness of the 1965 exiles against the New Order regime in Indonesia.

\section{2) Criticism of the Ideology of Racism}

In the short story entitled Sarma, there is data on the discussion of social class in the Netherlands, based on skin color. The top caste are Dutch citizens, the second caste is white immigrants (who come from other European countries), and the third caste is black and brown immigrants (immigrants from Suriname, Africa, and Southeast Asia). Consider the following data:

"Have a residence permit?" I investigated a little suspiciously, maybe an illegal immigrant.

"We all choose citizens here since Suriname was founded as a republic of its own. Damn it, it's hard to find work in the Netherlands, except for being coolies, third-class citizens."

Sarma rambles on as he pleases. Dutch first class, their second class dog, third class Sarma, he said. I was surprised, why did he say that. I tried to present to Sarma the reality of a more human era, according to European reasoning today (Tomodihardjo, 2006: 31 ).

The data is an expression of the ideology of racism that developed in the Netherlands, the development of the bourgeois and proletarian social classes (in Marxist theory), in the midst of the middle class, namely dogs. Dogs 
have a higher social class than coolies who are from Suriname, Africa, and people from the third world. In this data, the author implicitly offers a more humane ideology (humanism) that is in line with European reasoning today. The author believes that the ideology of humanity is the best solution.

ST in the short story Pagi di Garasi fights for the ideology of equal rights and degrees for all people regardless of race, color, and descent. In any part of the world, in modern society, people can move up in rank and position because it is based on the behavior of sycophants. Look at the data in the following dialog.

"Oh, yes, I can understand. But sir, do you think my fate is better? Monsieur! Here where can be promoted without licking. That I don't like. I don't think sir, either. Just so you know. But okay, I will try, who knows an experienced person like this Master is needed in my place. But don't get your hopes up. It's good that you apply for a job at the city-bus company. The chance is bigger. Monsieur Lacoste! According to the field sir. "

"Thank you, Mister Gardener, your suggestion is true. But please pay attention, sir, where is an African bus driver like me. I have to know myself. Mister Gardener. "

Hemmm. Mister Gardener fell silent. Monsieur Lacoste seems to be indulging in racial prejudice, he thought (Tomodihardjo, 2006: 79).

The dialogue between the Gardener and Lancoste figures can be understood that in Germany (the setting for the story) to get a certain position one has to be a curator of his superior. Racism still prevails in Germany, and Europe in general. In addition, certain professions or occupations must come from native citizens. There is an unwritten social class division. First social class, native German citizens. Second social class, other European citizens. The third social class, someone who comes from Africa, Asia and the third world. The exiles exist as inferior people. ST criticizes the class division and wants to liberate racism in any world.

\section{3) Criticism of the Ideology of Communism}

The political content that occurred in the country (Indonesia) at the change of power from Soekarno to Suharto, had an impact on the existence of Indonesian students who were abroad, both in China, Russia, and Europe (Netherlands, Germany and France). Indonesian students abroad had been abandoned because their scholarships have been cut off, wanted to return to their homeland afraid of being killed or becoming political prisoners on Nusakambangan Island and Buru Island. Students did not know what to do. Even working in a factory, being a cash cow by a dark organization from his own nation. Look at the following data.

Fellow friends? Did he really say it? It seemed that Markus understood my position in the circle of boundaries of the student community who had the same fate in several Eastern European countries: going back and forth when Bung Karno was knocked out. It is a critical and difficult time for them to exist abroad.

"Just tell from whom," insisted Markus.

"From the agency. Your own agent, "I was more desperate.

"El-Hakan huh?"

I'm not arguing. Markus knows, with that I confirmed it. El-Hakan is only one of the many dark labor middlemen in this metropolitan city, who ensnares many students well, working legally during vacancies (Tomodihardjo, 2006: 60).

This data can be interpreted that the political upheaval in Indonesia at the end of September 1965 and the change of power from Soekarno to Suharto, resulted in many students abroad being neglected because their scholarships were cut off. They are confused. If they want to stay abroad there is no guarantee to support them, while returning to Indonesia they are afraid to be killed or thrown to Buru Island as political prisoners. The scorching of the PKI people in the country was terrible. Human values that are championed by ST.

In the short story entitled Lintang Kemukus, there is data about the appearance of 'kemukus latitude' as a sign of a major disaster. The myth about 'kemukus latitude' in Java is believed to be true. Feelings of worry and fear about what will happen in Indonesia haunting everyone. Including the figure of Lastri, whose husband left the journalism service in Beijing, PRC. Look at the following data.

The alley was only gradually deserted when the old Pak RT explained that this natural phenomenon, which was worrying his residents, was only a cluster of kemukus latitude. The woman herself did not believe the gugon tuhon (superstition) that came out of Yu Sapar's mouth: "It is a sign that there will be disaster, Dik Lastri." However, the woman felt tremendous fear when she listened to the RRI Jakarta broadcast. The Generals were broadcast to be victims of murder, and finally riots, beatings, murders, arson, crackdowns occurred. It is not quite clear who the puppeteers are, how many puppets, how many puppets.

Not waiting long, together with Yu Sapar the woman burned all the newspapers containing her husband's writings. Which is sometimes difficult to chew reason. She was very scared, even only to bring her husband's writing. However, she believes in the sincerity and honesty of her husband's conscience (Tomodihardjo, 2006: 143).

This data can be understood implicitly that there is an ideology championed by the author, namely the ideology of humanism-socialist. The event of the September 30, 1965 tragedy, until now it has not been tracked who masterminded the incident. The murder victims were countless followers ("wayang/followers") of the amount. Puppeters and puppets, as symbols of leaders and people. 


\section{4) Critique of the Ideology of Liberalism}

The political struggle of marxism and liberalism raged in European countries, including Germany. Workers in Germany are polarized into native citizens, migrants from Europe, and migrants from the third world (Africa and Asia). Migrant workers from the third world are always months for workers who are native German citizens. Consider the debate between Martin and Gerd's character below.

As strangers, of course we feel uncomfortable hearing the angel's curses. So we clapped in our hearts when he argued with Martin - a student practice - during lunch in the canteen. Somehow at first, the debate escalated until it escaped Martin's mouth. "Sei nicht bloed! Alle Menschen sind Auslander! Don't be stupid! All humans are aliens! " Martin's rebuttal was so sharp, as if he were an ethnology expert with convincing arguments (Tomodihardjo, 2006: 53-54).

The data can be understood that there is a battle (conflict) between the ideology of marxism and liberalism. In marxist ideology, the division of the social class is determined by the bourgeoisie (owner) against the proletarian (working) class. On the other hand, in liberal ideology, social class division is based on capital ownership. There is ST's alignment with the ideology of humanist liberalism.

In a short story entitled Tinnitus, there is data about Western ideology that is instilled in children from an early age. European society that adheres to liberalism, prioritizes freedom, sportsmanship and anti-authority. Look at the following data.

I was flabbergasted at Jessica's unexpected answer. So frankly she talked about the reality of her parents.

I lived in her country for a long time, knowing a lot about the nature and pattern of European education: freedom, sportsmanship, anti-authority. But I felt how naive the words were coming out of Jessica's mouth this eight-year-old girl. In the least, she did not feel taboo or embarrassed to talk about what happened to her family (Tomodihardjo, 2006: 108).

There is an ideological conflict within the author regarding the behavior of a child named Jessica. Jessica, who was still eight year old, can already tell about her parents who divorced because they did not match anymore. European children are different from Javanese children (read: Indonesia). In Europe the values of freedom, sportsmanship and anti-authority of parents and rulers are instilled. On the other hand, children in Java are taught to obey their parents. There is a conflict between ideologies of liberalism and feudalism within ST.

\section{5) Criticism of the Ideology of Realism-Socialism}

In the short story entitled Cremation, there is data on the realism-socialist ideology adopted by the 1965 exile author named Agam Wispi. He accepted the feeling of loss and understood that one day there would be melancholy which created a longing for Indonesia. The focus was no longer on Indonesia, but as universal humanism. His work became more "human". With "Indonesia", He had an association that his literature was political literature. Look at the following data.

I'm not sure Wispi still knows us. Impressed he answered if he opened his mouth. His blank face gave the impression he forgot who we were. Every word that came out of his mouth sounded bland. The Dutch wheelchair pusher told us. Wispi has alzheimer, very forgetful, has been living in a nursing home for more than a year. Because of this he could not always attend funeral ceremonies, unless someone accompanied him. Wispi's current health condition is very sad. So dry and skinny. He is not the old Wispi anymore: a realist poet who is often cynical (Tomodihardjo, 2006: 100).

These data can be understood that the ideology adopted by Agam Wispi in poetry is socialist realism, which is based on universal humanism. The challenge itself exists for the Indonesian 1965 exile authors who were banished from their country.

\section{6) Criticism of the Ideology of Closure}

In the short story entitled Bernstein Jewel by ST, there is data about the attitude of not knowing each other in Moscow, Russia, to protect oneself from security forces. It is safer for foreigners in Russia not to greet each other, especially if they are different nationalities. Security and personal safety are at stake in Russia. Look at the following data.

Alex laughed and made fun of my stupidity. Fortunately, we were not long waiting for Aerovlot to depart for Moscow. On the bus leading up to the airplane steps I saw the German again, who was standing slightly to the center. I purposely approached him, stood by his side. He must know, but still he pretended not to see me. I did not expect from his mouth I heard a low voice. Es ist hier besser wenn wir nicht miteinander sprechen Here we better not talk to each other." I was speechless, realizing my own naivety. There are times when humans feel afraid to open their mouths (Tomodihardjo, 2006: 7).

The data can be interpreted that there is an inner conflict within the 'I' character, between wanting to greet a German acquaintance and pretending to be ignorant. In Russia, there are times when we do not greet each other for safety and personal protection. There is an ideological struggle of silence for safety and self-security.

7) Criticism of the Ideology of Secularism

In the short story entitled Dolls by ST, there is data on individual freedom to do business in any field, including 
the sex business. In a secular country like the Netherlands there is no sin. The sex business is advertised through television channels and social media. Look at the following data.

... When I got there I just realized that I was standing on the sidewalk in a red light area which left me flabbergasted. Max's former house and its left and right buildings had been transformed into a row of sex shops with erotica objects on the windows - I saw loincloths and the genitals of women and men in erect positions. The billboards shimmered in color swapping amidst the deafening music of the night. Presumably these are

"salted meat shops" according to Lo Shin in a compilation of Chinese literature, which tells the story of Shanghai in a time of immorality. I once borrowed the book from Ah Liong (Tomodihardjo, 2006: 20).

This data can be interpreted that the sex business is not prohibited in the Netherlands. In a country that adheres to the ideology of secularism, people can act anything as long as it does not interfere with the freedom of others. The sex business at traffic light intersections known as "salted meat" shops. Something contrary to what applies in Indonesia, God Almighty. ST implicitly adheres to the religious conscience which he believes to stay away from things that are immoral.

\section{Discussion}

ST in the short story collection Kera Di Kepala presents the concept of humanism-socialist ideology that he adheres to as opposed to marxism, socialism, liberalism, racism, secularism, and socialist realism. As the author of the 1965 Indonesian exile, ST is different from Utuy Tatan Sontani, Agam Wispi, and Sobroin Aidit. ST gave enlightenment that the Chinese communist ideology had obstacles to dominate the world due to opposition among the party elite. The ideologies of racism and secularism embraced by Germany and the Netherlands have been opposed by ST because they view migrant workers from the third world as looked down on compared to their domestic dogs. The freedom adopted by the German and Dutch states contradicts ST's inner conscience.

Hae (2011) notes that ST's horizon is very broad so that it is able to produce various works, not only as "ideological vehicles" but have transformed into literary works as the first and last bet for a writer. Resistance literature has changed enemies. His self-criticism of communism ideology echoes in his short stories. ST's short stories provide a good example of the existence of Indonesia's exil literature. When the bloc era ended and communism and marxism ideologies were obsolete, literature returned to its identity. Man who affirms his identity and at the same time comes with an endless dualism.

As a writer, ST believes that there is no best ideology in the world except socialist-humanism which can be juxtaposed with the Pancasila ideology in Indonesia. Socialist-humanism is different from marxism, liberalism and capitalism. Socialist-humanism is the third road (middle way) between marxism and capitalism. The presence of ST's short stories sheds light on the impasse between the Lekra (Lembaga Kebudayaan Rakyat)/(People's Cultural Institute) group and the Manikebu (Manifes Kebudayaan)/(Cultural Manifesto) group during the collapse of the Old Order era.

\section{Conclusion}

ST's short stories in the book Kera Di Kepala fight for a humanism-socialist ideology. ST was clear-minded in his literary works that he was not provoked by the ideology of communism and marxism, even though he was an exile writer in 1965 who was isolated in Germany until his death. The ideology of humanism-socialist rests on the third road between capitalism and socialism. The positive things in capitalism are taken away and the negative things are removed. Likewise, the positive in socialism is taken away, and the negative is discarded. The ideology of humanism-socialism in the future will illuminate the world from various ideological contestations that have been at a dead end.

\section{References}

Alba-Juez, Laura (2009) Perspectives on Discourse Analysis: Theory and Practice. Newcastle: Cambridge Scholars Publishing.

Aleida, Martin. (2017). Tanah Air Yang Hilang/Lost Homeland. Jakarta: PT Kompas Media Nusantara.

Choir, Badrul Munir (2018) "Ambivalence and Identity Crisis in Soeprijadi Tomodihardjo's Cucu Tukang Perang Short Story Collection: A Postcolonial Review," Kenosis. Vol. 4 No. December 2, 2018, p.

Fajar, Yusri (2017) Literature That Cross Boundaries and Identities. Yogyakarta: Basabasi

Foucault, Michel. (1972) The Archeology of Knowledge. New York: Pantheon Books.

Hae, Zen (2011) "Editor's Introduction," Soeprijhadi Tomodihardjo's Cucu Tukang Perang. Short Story CollectionYogyakarta: Akar Indonesia.

Hill, David T. (2008). "Knowing Indonesia Afar: Indonesian Exile and Australian Academics," Paper at the 17th Biennial Conference of The Asian Studies Association of Australia, Melbourne 1-3 July 2008.

Jorgensen, Marianne and Phillips, Louise J. (2002) Discourse Analysis as Theory and Method. London: Sage Publications.

Putra, Candra Rahma Wijaya (2018) "Describing the World in Exil Literature: Collection of Short Stories of Kera 
Di Kepala by Soeprijadi Tomodiharjo as a Travel Story," Proceedings of SENASBASA (National Seminar on Language and Literature), 3rd Edition, 2018, pp. 244-258.

Scheurich, James Joseph and Kathryn Bell McKenzie (2005) "Methodology Foucault On Archeology and Genealogy," in The Sage Handbook of Qualitative Research 2 (Third Edition) [Norman K Denzin and Yvonna S. Lincoln (Ed.)] California USA: Sage Publication .

Sipayung, Bambang Alfred. (2011). "Exiled Memories: The Collective Memory of Indonesian 1965 Exiles," (Thesis). Netherlands: Institute of Social Studies.

Zeng, Hong. (2010). The Semiotic of Exile in Literature. America: Palgrave Macmillan.

\section{Data Library}

Tomodihardjo, Soeprijadi (2006) Kera Di Kepala. Jakarta: KPG (Gramedia Popular Libraries). 